\title{
Identification of deletions in the human low density lipoprotein receptor gene
}

\author{
BERNHARD HORSTHEMKE* , ALISON DUNNING $†$, AND \\ STEVE HUMPHRIES† \\ From *the Biochemistry Department, St Mary's Hospital Medical School, London W2 1PG; and the \\ Charing Cross Sunley Research Centre, London W6 8LW.
}

SUMMARY DNA samples from 70 unrelated UK patients with heterozygous familial hyperi cholesterolaemia were screened by Southern blot hybridisation with a 5' fragment of the humari low density lipoprotein (LDL) receptor cDNA. In the majority of cases, the restriction fragmen $\vec{E}$ pattern of the LDL receptor gene was indistinguishable from that observed in normal subjectso However, three patients were found to have a deletion of approximately $1 \mathrm{~kb}$ in the centraL portion of the gene. Mapping experiments indicated that in two patients a similar deletion has occurred that includes all or part of exon 5, and in the third patient a deletion has occurred that5 includes exon 7. Taking into account our previously described patient with a deletion in the $3^{D}$ part of the gene, this means that in four out of $70 \mathrm{UK}$ patients with familial hypercholesterolaemi $\mathscr{E}_{0}$ $(6 \%)$, the defect is caused by a detectable deletion of part of the coding portion of the low density lipoprotein receptor gene.

Familial hypercholesterolaemia $(\mathrm{FH})$ is caused by a reduction in cellular low density lipoprotein (LDL) uptake due to defects in the LDL receptor. ${ }^{1} 2$ The disease is clinically characterised by raised serum and LDL cholesterol levels, tendon xanthomata in some cases, and increased risk of myocardial infarction after the age of 35 years. ${ }^{3-5}$ With one person in 500 carrying a mutant LDL receptor gene, FH contributes significantly to the incidence of coronary artery disease. Recently, the full length cDNA and the entire LDL receptor gene have been cloned. ${ }^{67}$ So far three deletions, ${ }^{8-10}$ one small insertion, and one point mutation ${ }^{11}$ have been reported. All these mutations are located in the $3^{\prime}$ third of the $45 \mathrm{~kb}$ gene. Here we have used a $5^{\prime}$ cDNA fragment to search for gene deletions or rearrangements in the $5^{\prime}$ part of the gene.

\section{Materials and methods}

Blood samples were collected from heterozygous FH patients attending lipid clinics at the Metabolic Unit at St Mary's, St George's, St Thomas's, and

$\ddagger$ Present address: Institut für Humangenetik. Universitätsklinikum Essen. Hufelandstrasse 55, D-4300 Essen 1. Federal Republic of Germany. Received for publication 15 July 1986. Accepted for publication 2 September 1986
Hammersmith Hospitals. Lipoproteins were anal sed using standard techniques and patient criteriz were those previously described. ${ }^{12}$ Briefly, patien have plasma LDL cholesterol levels above 4.07 $\mathrm{mmol} / \mathrm{l}$, tendon xanthomata in some cases, and family history of premature myocardial infarction $\dot{\alpha}$ type IIa hyperlipidaemia or both.

GENE PROBES FOR THE LDL RECEPTOR GENE The full length cDNA clone pLDLR-3 was a kind gift from Dr D W Russell, Dallas, USA. Plasmie DNA was prepared by the alkaline lysis method ${ }_{0}^{13}$ and was then digested with HindIII and BglH (Anglian Biotechnology). The resulting $1.7 \mathrm{~kb}$ ? cDNA fragment (nucleotides 1 to 1706) was isolate on a $1 \%$ low gelling temperature agarose gel (BRIF) and purified as described. ${ }^{14}$ This probe was theo labelled to a specific radioactivity of greater than 18 $\mathrm{cpm} / \mu \mathrm{g}$ by random oligonucleotide priming (PGS Biochemicals) using $\left[{ }^{32} \mathrm{P}\right] \mathrm{dCTP}$ at $800 \mathrm{Ci} / \mathrm{mm}$ ब (Amersham). ${ }^{15}$

DNA ANALYSIS

Blood samples were collected in EDTA tubes ang frozen at $-20^{\circ} \mathrm{C}$. Total genomic DNA was prepare from leucocytes by a Triton X 100 lysis method $\frac{\Phi 6}{\mathbb{D}}$ DNA $(5 \mu \mathrm{g})$ was digested with restriction enzymes, separated on a $0.7 \%$ agarose gel, and transferred 
Zetabind filters (AMF Cuno). Hybridisation and autoradiography were as described previously. ${ }^{9}$

\section{Results}

DNA samples from 70 unrelated $\mathrm{FH}$ patients were digested with $B g I I I$ and analysed by Southern blot hybridisation with the $5^{\prime}$ cDNA fragment. This probe hybridises to exons 1 to 11 , which are contained in $B g l I I$ fragments of $10 \mathrm{~kb}, 13 \mathrm{~kb}$, and 9.5 $\mathrm{kb}$. An example of six digests is shown in fig 1 . Since the most $5^{\prime} 10 \mathrm{~kb}$ fragment contains only one exon, the hybridisation signal is much fainter than with the other bands and can be seen only after very long exposures (not shown). Three of the patients (PO, $\mathrm{JA}$, and $\mathrm{KL}$ ), who are heterozygous for $\mathrm{FH}$, were found to have an additional fragment of approximately $12 \mathrm{~kb}$.

To determine whether this pattern was the product of a rare $B g l \mathrm{II}$ polymorphism or of deletions in the gene, we performed EcoRI and EcoRI/BamHI single and double digests. Southern blot filters were hybridised with the $1.7 \mathrm{~kb} \mathrm{5}$ cDNA probe (fig 2) and the pattern of fragments observed was compared with the expected fragments predicted from the restriction map of the LDL receptor gene ${ }^{7}$ (fig 3). Samples from the three patients also contain additional fragments with these enzymes, indicating that the patterns seen are due to gene deletions rather than to a $B g l I I$ polymorphism. Patients $\mathrm{PO}$ and JA show the same pattern: the probe detects a larger $11 \mathrm{~kb} E c o \mathrm{RI}$ fragment, while the $10 \mathrm{~kb}$ and $1.7 \mathrm{~kb}$ fragments are present at only half the normal intensity. This indicates that the deletion in one allele of both these patients includes the EcoRI site in exon 5 and suggests that all or part of exon 5 has been deleted. Thus, the $11 \mathrm{~kb}$ fragment is a product

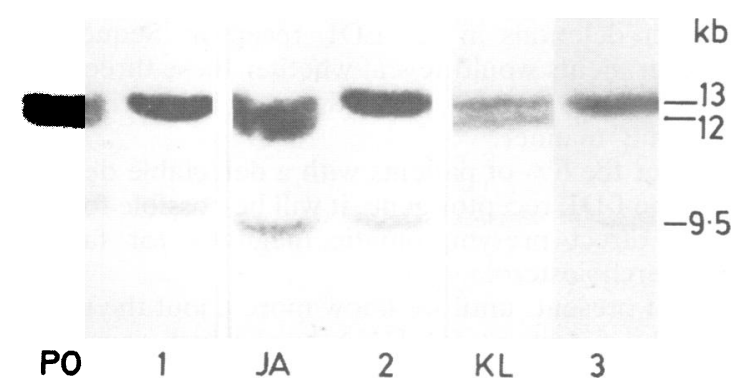

FIG 1 Southern blot hybridisation of BgllI cleaved genomic DNA from patients $P O, J A$, and $K L$ and normal subjects 1, 2, and 3. Fragment sizes were calculated from molecular size standards of bacteriophage $\lambda$ DNA cleaved with HindIII.

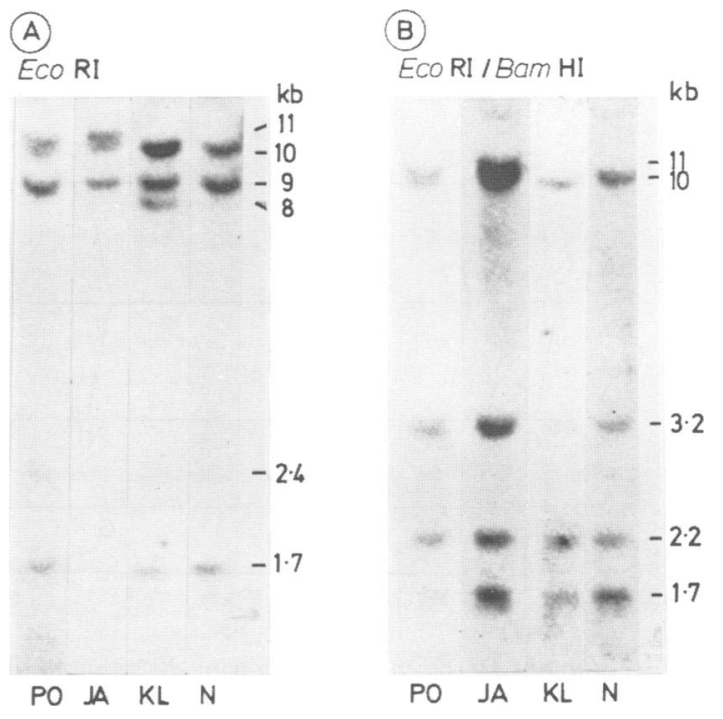

FIG 2 Southern blot hybridisation of $(A)$ EcoRI and (B) EcoRI/BamHI cleaved genomic DNA from patients $P O$, $J A$, and $K L$ and one normal subject $N$.

of the normal $10 \mathrm{~kb}$ plus the $1.7 \mathrm{~kb}$ fragments minus the deletion.

The pattern of hybridising fragments in DNA from patient $\mathrm{KL}$ indicates that the deletion is in a different region of the gene from patients $\mathrm{PO}$ and JA. In patient KL, the probe detects an additional 8 $\mathrm{kb}$ EcoRI fragment, which could arise from a deletion of roughly $1 \mathrm{~kb}$ from the normal $9 \mathrm{~kb}$ fragment. In the EcoRI/BamHI double digests, the hybridisation intensity of the $3.2 \mathrm{~kb}$ band is reduced, while the intensity of the $2 \cdot 2 \mathrm{~kb}$ band is increased. This indicates that there has been a deletion of roughly $1 \mathrm{~kb}$ from the $3.2 \mathrm{~kb}$ fragment containing exon 7 , resulting in the detection of a fragment of $2 \cdot 2 \mathrm{~kb}$.

\section{Discussion}

Of the 70 patients with $\mathrm{FH}$ that we have examined, three have a detectable deletion in the central part of the gene. From our preliminary mapping experiments it is possible to estimate the extent of these deletions. For patients PO and JA, the deletion has removed all or part of exon 5 which codes for the final part of the LDL receptor ligand binding domain, and for patient KL, the deletion affects exon 7, which codes for the first part of the 'stem' region of the receptor. ${ }^{67}$ These deletions clearly interrupt normal LDL receptor function and cause FH. If, however, a deletion has excised an entire 


\begin{tabular}{l|l|llllllll|l|l|l|l|l|l}
2 & 3 & & 4 & 5 & 6 & 7 & 8 & 9 & 10 & 11 & 12 \\
\hline & & & & & & & & & & & & & & & \\
\hline
\end{tabular}
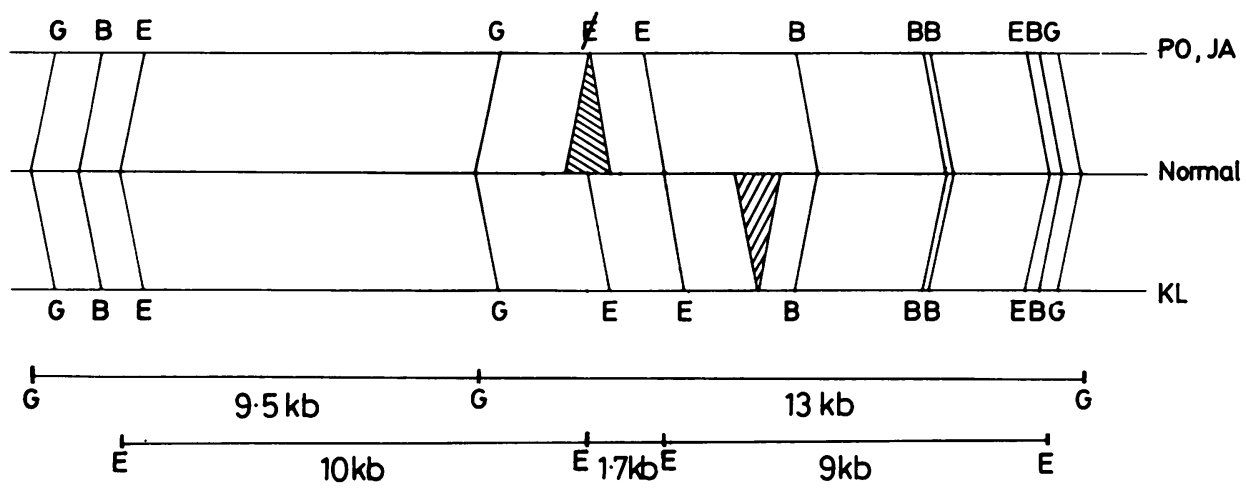

FIG 3 Map of $L D L$ receptor gene showing the positions of the deletions relative to the normal gene. The restriction enzyme $\vec{z}$

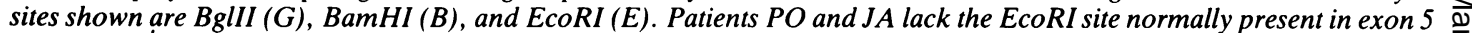
(shown as \#). The relative positions of exons 2 to 12 are shown together with the sizes in kb of the normal BglII and EcoRI $\stackrel{\widehat{S}}{د}$ fragments.

exon rather than just a portion of one, then it is possible that the reading frame of the mRNA is not altered when the introns are spliced out. In the LDL receptor gene, exon 4 ends with the first base of a codon triplet, while both exon 5 and exon 6 start with two bases to complete a codon triplet. ${ }^{6}$ It is thus possible that in patients $\mathrm{PO}$ and $\mathrm{JA}$, with a deletion of exon 5, exon 4 may be spliced onto exon 6 during processing of the RNA transcript. Translation of this mRNA should result in the production of a receptor protein lacking amino acids 211 to 292 .

Similarly, in patient KL, where exon 7 is affected, exons 6 and 8 could be spliced together to form an mRNA that would be translated to give a protein lacking amino acids 293 to 374 . It will be possible to test these hypotheses by culturing fibroblasts from the patients and examining the processing and function of the receptor proteins using Western blotting techniques.

At the resolution of the mapping experiments we have carried out, the deletion in patients $\mathrm{PO}$ and $\mathrm{JA}$ appears to be identical. A more detailed comparison will require the isolation and the sequencing of this allele of the genes from the two patients. It is possible that the deletion may have occurred independently on two occasions, or more likely that the patients have both inherited the defective gene from a common ancestor. To date we have not been able to determine a shared family history for these patients.
We have now detected four deletions of the LDL receptor gene among the $70 \mathrm{FH}$ patients we have screened, the three reported here together with the्ष previously reported deletion in the $3^{\prime}$ region of the gene. ${ }^{9}{ }^{17}$ Such deletions thus appear to be a signifi $\overrightarrow{\overrightarrow{0}}$ cant cause of $\mathrm{FH}(\sim 6 \%)$ in the UK population. This high frequency of LDL receptor gene deletions can perhaps be explained by the frequent occurrence of highly repetitive Alu repeat sequence present in the intervening sequences and 3 ' untranslated region of this gene. ${ }^{1017}$ Mechanisms of recombination due to either homologous or non-homologous pairing of̆ Alu repeat sequence, followed by crossing ovee during meiosis, have been invoked to explain the other deletions in the LDL receptor. Sequencing experiments would reveal whether these three dele $\rightarrow$ tions in the central part of the gene have arisen in aE. similar manner.

For the $6 \%$ of patients with a detectable deletion of the LDL receptor gene, it will be possible to carryo out direct presymptomatic diagnosis for familiaks hypercholesterolaemia.

At present, until we know more about the natureo of the defects at the DNA level which cause $\mathrm{FH}$ presymptomatic DNA diagnosis for the remainder of the patients will require the use of restriction fragment length polymorphisms in family studies. ${ }^{180}$

This work was supported by grants from the Britisl Heart Foundation (RG5) and the Medical Researchp 
Council. We thank Dr G Thompson and Professors V Wynn, B Lewis, R West, and J Lloyd for supplying blood samples, and also Dr D W Russell for supplying the LDL receptor $\mathrm{CDNA}$ clones. $\mathrm{BH}$ is in receipt of an EMBO long term fellowship.

\section{References}

1 Brown MS, Goldstein JL. Expression of the familial hypercholesterolaemia gene in heterozygotes. Mechanisms for a dominant disorder in man. Science 1974;185:61-3.

2 Brown MS, Goldstein JL. Familial hypercholesterolaemia. Defective binding of lipoproteins to cultured fibroblasts associated with impaired regulation of 3-hydroxy-3-methylglutaryl coenzyme A reductase activity. Proc Natl Acad Sci USA 1974:71:788-92.

3 Harlan WR, Graham JB, Estes EH. Familial hypercholesterolaemia, a genetic and metabolic study. Medicine (Baltimore) 1966;45:77-110.

4 Goldstein JL, Schrott HG, Hazzard WR, Bierman EL, Motulsky AG. Hyperlipidaemia in coronary heart disease. Part 2. Genetic analysis of lipid levels in 176 families and delineation of a new inherited disorder, combined hyperlipidaemia). J Clin Invest 1973;52:1544-68.

5 Frederickson DS, Goldstein JL, Brown MS. The familial hyperlipoproteinaemias. In: Stanbury JB, Wyngaarden JB, Frederickson DS, eds. The metabolic basis of inherited disease. New York: McGraw-Hill, 1978:604-55.

6 Yamamoto T, Davis LG, Brown MS, et al. The human LDL receptor. a cystine-rich protein with multiple Alu sequences in its mRNA. Cell 1984;39:27-38.

7 Sudhof TC, Goldstein JL, Brown HS, Russell DW. The LDL receptor gene: a mosaic of exons shared with different proteins. Science 1985;228:815-22.

8 Lehrman MA, Schneider WJ, Sudhof TC, Brown MS, Goldstein JL, Russell DW. Mutation in LDL receptor; alu-alu recombination deletes exons encoding transmembrane and cytoplasmic domains. Science 1985;227:140-6.

9 Horsthemke B, Kessling AM, Seed M, Wynn V, Williamson R, Humphries SE. Identification of a deletion in the low density lipoprotein (LDL) receptor gene in a patient with familial hypercholesterolaemia. Hum Genet 1985;71:75-8.

10 Lehrman MA, Russell DW, Goldstein JL, Brown MS. Exon-alu recombination deletes 5 kilobases from the low density lipoprotein receptor gene producing the null phenotype in familial hypercholesterolemia. Proc Natl Acad Sci USA 1986;83: 3679-84.

11 Lehrman MA, Goldstein JL, Brown MS, Russell DW, Schneider WJ. Internalization-defective $\mathrm{LDL}$ receptors produced by genes with nonsense and frameshift mutations that truncate the cytoplasmic domain. Cell 1985;41:735-43.

12 Humphries SE, Donald JA, McFadden JJP, et al. The use of polymorphic DNA and protein markers for the third complement component for determining linkage of familial hypercholesterolaemia. Atherosclerosis 1984;52:267-78.

13 Maniatis T, Fritsch EF, Sambrook J. Molecular cloning (a laboratory manual). Cold Spring Harbor, New York: Cold Spring Harbor Laboratories, 1982:90-1.

14 Maniatis T, Fritsch EF, Sambrook J. Molecular cloning (a laboratory manual). Cold Spring Harbor, New York: Cold Spring Harbor Laboratories, 1982:170.

15 Feinberg AP, Vogelstein A. A technique for radio-labelling DNA restriction endonuclease fragments to high specific activity. Anal Biochem 1984;137:266-7.

16 Kunkel LM, Smith KD, Boyer SH, et al. Analysis of human Ychromosome-specific reiterated DNA in chromosome variants. Proc Natl Acad Sci USA 1977;74:1245-9.

17 Horsthemke B, Beisiegel U, Dunning A, Having JR, Williamson R, Humphries S. Non-homologous crossing over between two alu-repetitive DNA sequences in the LDL receptor gene: a possible mechanism for a novel mutation in a patient with familial hypercholesterolaemia. Eur J Biochem (in press).

18 Humphries SE, Kessling AM, Horsthemke B, et al. A common DNA polymorphism of the low-density lipoprotein (LDL) receptor gene and its use in diagnosis. Lancet 1985;i:1003-5.

Correspondence and requests for reprints to Dr S Humphries, Charing Cross Sunley Research Centre, Lurgan Avenue, London W6 8LW. 